\title{
Residual, Corrosion \& Tribological Behavior of HVOF Sprayed Sustainable Temperature-Dependent Carbon-Based Hybrid Composite Coating
}

\author{
Ankit Tyagi 1,2,* - Qasim Murtaza ${ }^{1}$ - Ravinderjit Singh Walia ${ }^{3}$ \\ ${ }^{1}$ Delhi Technological University, Department of Mechanical Engineering, India \\ ${ }^{2}$ SGT University, Department of Mechanical Engineering, India \\ ${ }^{3}$ Punjab Engineering College, Department of Production \& Industrial engineering, India
}

At present, cost-effective coatings that cause less pollution are in great demand; to decrease frictional losses, carbon-based hybrid composite coatings have been developed using a high-velocity oxy-fuel (HVOF) spray process. The microstructural, tribological, corrosion, and mechanical properties of these coatings have been evaluated using high-resolution X-ray diffraction (HRXRD), field emission scanning electron microscopy-Energy dispersive X-ray Spectroscopy (FESEM-EDS), Raman spectrum, Vickers micro-hardness tester, $\mu-360 \cos (\alpha)$ residual stress analyser, corrosion tester, and high temperature tribometer. The residual stress, corrosion and tribological behaviour at high temperatures were investigated using a pin-on-disc high-temperature tribometer. The tribological performance was evaluated using a high-temperature tribometer, and the experimental result shows that a coefficient of friction (COF) varies from 0.12 to 0.52 , while wear results were in the range of $45 \mu \mathrm{m}$ to $120 \mu \mathrm{m}$, as the test condition of temperature ranging from $50^{\circ} \mathrm{C}$ to $350{ }^{\circ} \mathrm{C}$, load from $60 \mathrm{~N}$ to $90 \mathrm{~N}$ and sliding velocity from $0.1 \mathrm{~m} / \mathrm{s}$ to 0.4 $\mathrm{m} / \mathrm{s}$ respectively. The experimental results of corrosion testing show that the mass loss decreases from $0.10 \mathrm{~g}$ to $0.04 \mathrm{~g}$, when samples were dipped for $1 \mathrm{~h}$; when the samples were dipped for $8 \mathrm{~h}$, the mass loss of hybrid composite coating varied from $0.12 \mathrm{~g}$ to $0.045 \mathrm{~g}$. The tribological test showed a $78.9 \%$ increase in micro-hardness, a $78 \%$ decrease in residual stress, and $60 \%$ and $62.5 \%$ decreases in mass loss due to corrosion at $1 \mathrm{~h}$ and $8 \mathrm{~h}$, respectively, a $76.9 \%$ decrease in COF and $62.5 \%$ reduction in the wear at test condition of $350^{\circ} \mathrm{C}$ temperature, a sliding velocity of $0.4 \mathrm{~m} / \mathrm{s}$ and $90 \mathrm{~N}$ load.

Keywords: HVOF carbon coating, FESEM, HRXRD, Raman spectra test, corrosion, wear test.

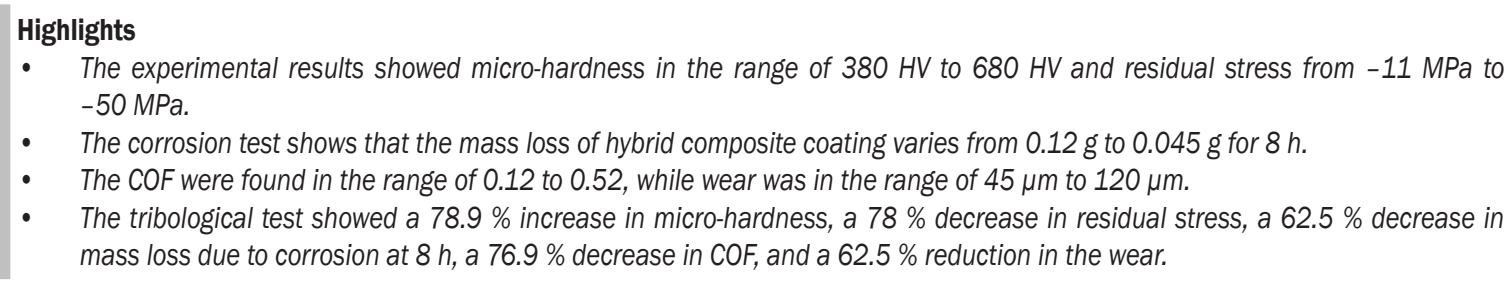

\section{O INTRODUCTION}

The past century observed a wide range of development in the automotive, marine and aerospace industries. Among assorted challenges in the automotive and marine environment, cavitation and erosion are prominent causes in the failure of engineering components, such as pumps, engines, blades, and ship propellers [1] and [2]. The general phenomenon in hydraulic systems involves a bombardment of gas bubbles on the component surface that leads to erosion, and fatigue failure, which finally deteriorate the performance of valuable and crucial equipment [3] and [4]. Surface modification offers an economical and effective methodology to tackle cavitation and erosion problem on the component surface. Thermal spray is a surface modification method that can fabricate coatings with broad feedstock materials and high deposition rate and effective for cavitation and erosion protection [5] and [6]. The experimental investigation of Qiao et al. [7] observed that high-velocity oxy-fuel (HVOF) sprayed Fe amorphous coating exhibits high cavitation erosion resistance. Among coating materials, tungsten carbide (WC)-based composite coatings or hard metals are significant sort of materials with a diverse range of governable properties, such as surface energy, wear, hardness, corrosion resistance and toughness, due to their unique virtues of the binder phase and hard phase [8] to [12]. Recently, a comparative study was carried out by Zhang et al. [13], which determined that among several thermal spray coating, WC based composite coating have excellent cavitation erosion resistance. Detonation spraying, HVOF spraying, plasma 
spraying and cold spraying are the most commonly used techniques for WC-based coating deposition [14] to [16]. Cheng et al. [17] studied the wear resistance behaviour, hardness and elastic behaviour of arcsprayed coating and concluded that all the properties are enhanced with high $\mathrm{H} / \mathrm{E}, \mathrm{H}^{3} / \mathrm{E}^{2}$, and $\eta$ value. The experimental study further concluded that high $\mathrm{H} / \mathrm{E}$, $\mathrm{H}^{3} / \mathrm{E}^{2}$, and $\eta$ value enhances product and service life and other properties. Another study, by Hong et al. [18] on the $\mathrm{Cr} 3 \mathrm{C} 2-\mathrm{NiCr}(\mathrm{CN})$ and $\mathrm{WC}-\mathrm{Cr} 3 \mathrm{C} 2-\mathrm{Ni}$ (WCN) HVOF sprayed coating for corrosion and wear resistance concluded that $\mathrm{CN}$ coating retains lower $\mathrm{E}$ and $\mathrm{H}$ values with high porosity, while $\mathrm{WCN}$ coating has higher $\mathrm{H}^{3} / \mathrm{E}^{2}$ and $\mathrm{H} / \mathrm{E}$ values and lower porosity. The HVOF method is the best apposite process for ceramic coating materials due to the low flame temperature and high velocity of melted particles. According to [19], HVOF-based WC-10Co-4Cr coating exhibits excellent slurry erosion resistance on comparing with uncoated steel plate. One fascinating outcome for WC-based coating were improvements in toughness and hardness, using nano-sized WC particles [20] and [21] and, due to decarburization [22], occasionally negative results were reported. To overcome decarburization, multimodal feedstock powder was used but employment of HVOF techniques proves effective in enhancement of particle velocity and in lowering of flame temperature [23] and [24].

Corrosion and erosion are critical and an inevitable issue for the constituent's surface exposed to the engine and marine environment that typically complicate the problem. Wentzel and Allen [25] investigated pure Ni binder and observed poor wear and corrosion wear performance despite good static corrosion results. The combined mechanisms are crucial for the coating fabrication and selection of material for coating, which has not been implicit in previous studies.

The present work aims to explicate the influence of HVOF sprayed sustainable temperature-dependent carbon-based hybrid composite coating on wear, coefficient of friction (COF), corrosion, residual stress, and hardness. The analysis of COF, wear, and corrosion behavior was well supported by field emission scanning electron microscopy (FESEM), Raman spectrum and high-resolution X-ray diffraction (HRXRD) observation. This work focused to evaluates the microstructure, surface morphology, tribological and mechanical properties of hybrid composite coating, using a high-temperature pinon-disk tribometer, at test condition of temperature ranging from $50{ }^{\circ} \mathrm{C}$ to $350{ }^{\circ} \mathrm{C}$, load from $60 \mathrm{~N}$ to
$90 \mathrm{~N}$ and sliding velocity from $0.1 \mathrm{~m} / \mathrm{s}$ to $0.4 \mathrm{~m} / \mathrm{s}$, respectively

\section{EXPERIMENTAL}

\subsection{Coating Preparation}

Carbon-based hybrid composite powders were used for the fabrication of high quality coating for wear resistance applications. The fabrication process initially involved mixing of micron size $\mathrm{C}+\mathrm{Mo}+\mathrm{WC}+\mathrm{TiO}_{2}+\mathrm{Al}_{2} \mathrm{O}_{3}$ powders of the same proportion using a ball mill process followed by thermal spraying and sintering. The ball-milling operation was performed for homogeneous and uniform distribution of carbon powder throughout the composite powder. A MEC - HIPOJET ${ }^{\circledR} 2700 \mathrm{HVOF}$ spraying system was used to deposit a carbon-based hybrid composite coating on $100 \mathrm{~mm} \times 100 \mathrm{~mm} \times 50$ $\mathrm{mm}$ steel substrate. Prior to spraying, the substrates were properly cleaned with emery paper and were grit-blasted with 60 mesh $\mathrm{SiC}$, using the pressurized air jet of sandblaster with a blasting pressure of $70 \mathrm{psi}$ from $50 \mathrm{~mm}$ distance, followed by surface cleaning with acetone. The optimized spraying parameters for HVOF coating were $45 \mathrm{~m}^{3} / \mathrm{h}$ oxygen flux, $15 \mathrm{l} / \mathrm{h}$ LPG flux, $100 \mathrm{~mm}$ spraying distance, $60 \mathrm{~g} / \mathrm{min}$ powder feed rate.

\subsection{Characterization \& Wear Test}

The surface morphology and structural composition of fabricated coating were characterized using JOEL FESEM-EDS. PANalytical HRXRD systems were used to identify and confirm the phase and crystal structure using the $\mathrm{Cu}$ anode material in Bragg mode. A Renishaw micro-Raman spectrometer was deployed to identify elemental peaks of fabricated coating with spectral range $\left(3500 \mathrm{~cm}^{-1}\right)$ and resolution about $1 \mathrm{~cm}^{-1}$.

The micro-hardness of the developed carbon coating was evaluated using an Hm2000S Make Vickers hardness tester (Fischer scope). The microhardness tester with a diamond stylus was used to perform tests with indentation time of $20 \mathrm{~s}$, dwell time of $5 \mathrm{~s}$ and a maximum applied load of $1000 \mathrm{mN}$ on the stylus. The residual stress analyser $(\mu-\mathrm{X} 360, \mathrm{XRD})$ was used to evaluate the internal stresses developed on the carbon coatings.

The pin-on-disk tribometer was used to examine the tribological behavior (COF \& wear) of carbonbased hybrid composite coatings. The DHM850 high-temperature tribometer, with a temperature 
range of ambient $-800{ }^{\circ} \mathrm{C}$, load $20 \mathrm{~N}$ to $200 \mathrm{~N}$ and sliding velocity of $0.1 \mathrm{~m} / \mathrm{s}$ to $-10 \mathrm{~m} / \mathrm{s}$ was used for the experimental investigation of wear and COF. The test conditions of wear and COF were given in Table 1 , where $\mathrm{C}$ is the carbon-based hybrid coating, and suffixes $01,02,03$ and 04 were used to differentiate the test conditions of the composite coating. The experimental tests for $\mathrm{COF}$ and wear were conducted with ASTM G99 standards without lubrication, G99 grade pin with a diameter of $8 \mathrm{~mm}$ and a surface roughness of $10 \mathrm{~nm}$; the temperature varies from 50 ${ }^{\circ} \mathrm{C}$ to $350{ }^{\circ} \mathrm{C}$, the load from $60 \mathrm{~N}$ to $90 \mathrm{~N}$, and the sliding velocity from $0.1 \mathrm{~m} / \mathrm{s}$ to $0.4 \mathrm{~m} / \mathrm{s}$.

The corrosion test was conducted with ASTM G111 standards in an electrolyte solution. The electrolyte solution was formed by mixing $3.5 \mathrm{wt} \%$ of $\mathrm{NaCl}$ powder in $1000 \mathrm{ml}$ distilled water. The samples of the high-temperature wear test were dipped in the electrolyte solution for 1 and $8 \mathrm{~h}$, for mass loss analysis.

Table 1. Details of experiment for wear test

\begin{tabular}{clcccc}
\hline No. & Parameter & C01 & C02 & C03 & C04 \\
\hline 1 & Temperature $\left[{ }^{\circ} \mathrm{C}\right]$ & 50 & 150 & 250 & 350 \\
\hline 2. & Load $[\mathrm{N}]$ & 60 & 70 & 80 & 90 \\
\hline 3. & Sliding velocity $[\mathrm{m} / \mathrm{s}]$ & 0.1 & 0.2 & 0.3 & 0.4 \\
\hline
\end{tabular}

\section{RESULTS \& DISCUSSIONS}

\subsection{Coating Characterization}

Fig. 1a to c illustrates the FESEM image of the surface and cross-sectional morphology along with bonding conformity of carbon-based hybrid composite coatings. It is quite clear from FESEM image at $\times 1000$ and $\times 500$ that flake-like structures are seen along with presence of semi-molten, molten, and un-melted grains of composite particles along with formation of lamellae. Fig. 1c shows carbon coating was deposited uniformly and homogeneously, ranging from $400 \mu \mathrm{m}$ to $450 \mu \mathrm{m}$. Fig. $1 \mathrm{~d}$ to $\mathrm{f}$ shows the EDS mapping results of composite coating and confirms the deposition of $\mathrm{wt} \%$ in the developed coating as $28 \%$ carbon, $8 \%$ oxygen. Fig. 1f shows the HRXRD spectra on the carbon-based hybrid composite coating. In the present case, peaks at $2 \theta=9^{\circ}$ to $9.5^{\circ}, 2 \theta=18.5^{\circ}$ to $19^{\circ}$, $2 \theta=26^{\circ}$ to $27^{\circ}, 2 \theta=35^{\circ}$ to $36^{\circ}, 2 \theta=48^{\circ}$ to $48.5^{\circ}$ and at $2 \theta=54^{\circ}$ to $55^{\circ}, 2 \theta=65^{\circ}$, and $73^{\circ}$ to $78^{\circ}$ and many other small peaks respectively were observed on the fabricated coating. The prominent peaks on the coating were at $2 \theta=26^{\circ}$ to $27^{\circ}, 2 \theta=35^{\circ}$ to $36^{\circ}$, and $2 \theta=48^{\circ}$ to $48.5^{\circ}$. The HRXRD results confirm the formations of carbides, oxides and sulphides phases within the coating [26]. Fig. 1g shows the captured Raman spectra peak on the developed coating with the presence of hybridized carbon peak. To examine the structural properties of coating materials, Raman spectroscopy has been used by the researchers. In the present research, prominent peaks were observed at $1120 \mathrm{~cm}^{-1}$ to $1140 \mathrm{~cm}^{-1}, 1340 \mathrm{~cm}^{-1}$ to $1360 \mathrm{~cm}^{-1}$ and $1550 \mathrm{~cm}^{-1}$ to $1590 \mathrm{~cm}^{-1}$ on the carbon-based hybrid composite coating. It is noted that peaks around 1340 $\mathrm{cm}^{-1}$ to $1350 \mathrm{~cm}^{-1}$ and at $1120 \mathrm{~cm}^{-1}$ to $1140 \mathrm{~cm}^{-1}$ show $\mathrm{sp}^{1}$ or $\mathrm{sp}^{2}$ hybridized carbon deposition on the developed coating, while peaks around $1550 \mathrm{~cm}^{-1}$ to $1590 \mathrm{~cm}^{-1}$ shows presence of $\mathrm{sp}^{3}$ hybridization with presence of diamond-like carbon (DLC) coating as testified in formerly research [26] to [28].

\subsection{Micro-Hardness}

The micro-hardness of carbon-based hybrid composite coatings deposited using the HVOF process is shown in Fig. 2a. The experimental results of hardness for fabricated coating shows that as the test condition of temperature ranging from $50{ }^{\circ} \mathrm{C}$ to $350{ }^{\circ} \mathrm{C}$, load from $60 \mathrm{~N}$ to $90 \mathrm{~N}$ and sliding velocity from $0.1 \mathrm{~m} / \mathrm{s}$ to 0.4 $\mathrm{m} / \mathrm{s}$, respectively, rapidly increase hardness from 380 $\mathrm{HV}$ to $680 \mathrm{HV}$. The hardness was found to increase of $79 \%$ at the test condition of $90 \mathrm{~N}$ load, $0.4 \mathrm{~m} / \mathrm{s}$ sliding velocity, and $350{ }^{\circ} \mathrm{C}$ temperature. The increase in hardness is due to the hard-ceramic particles, formation of oxides, carbides and sulphides layers, the agglomerate size of powders and the strong adhesive force between coating particles [29]. The experimental result shows as the temperature, load, and velocity increase, the micro-hardness of the carbon-based hybrid composite coating increases significantly, as studied by Tyagi et al. [30], and similar trends were also attained in the present hardness test. Matikainen et al. [31] investigated HVOF-developed coating, and experimental result shows that higher velocity particles enhance the hardness of the coating [32].

\subsection{Residual Stress}

The residual stress of carbon-based hybrid composite coatings fabricated using HVOF process is shown in Fig. 2b. Mathematically, the residual stress was determined by accurately measuring the position of the Debye rings using the Eqs. (1) and (2) and as shown in Fig. 3. Residual stresses on the coated samples are because biaxial applied load and thermal stresses developed on the body. The experimental results of residual stress for composite coating shows that as the 
a)

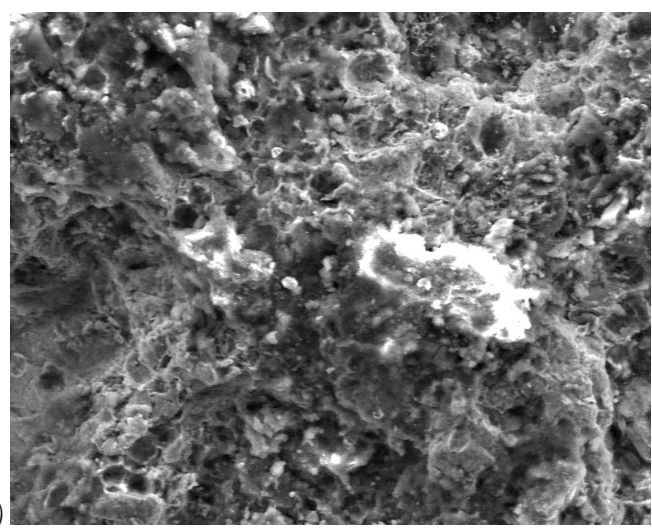

c)

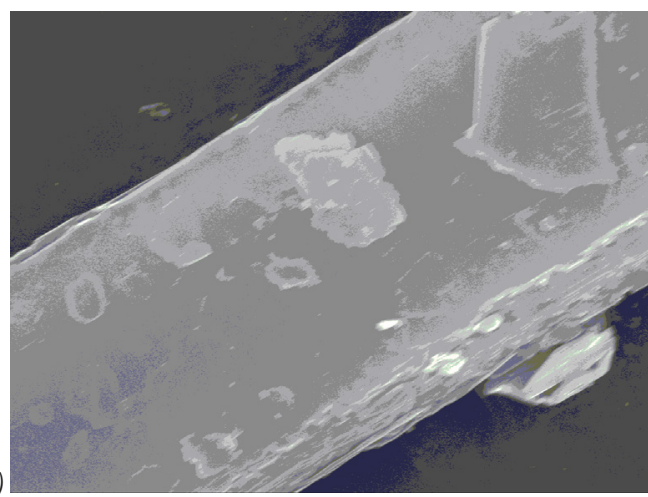

b)
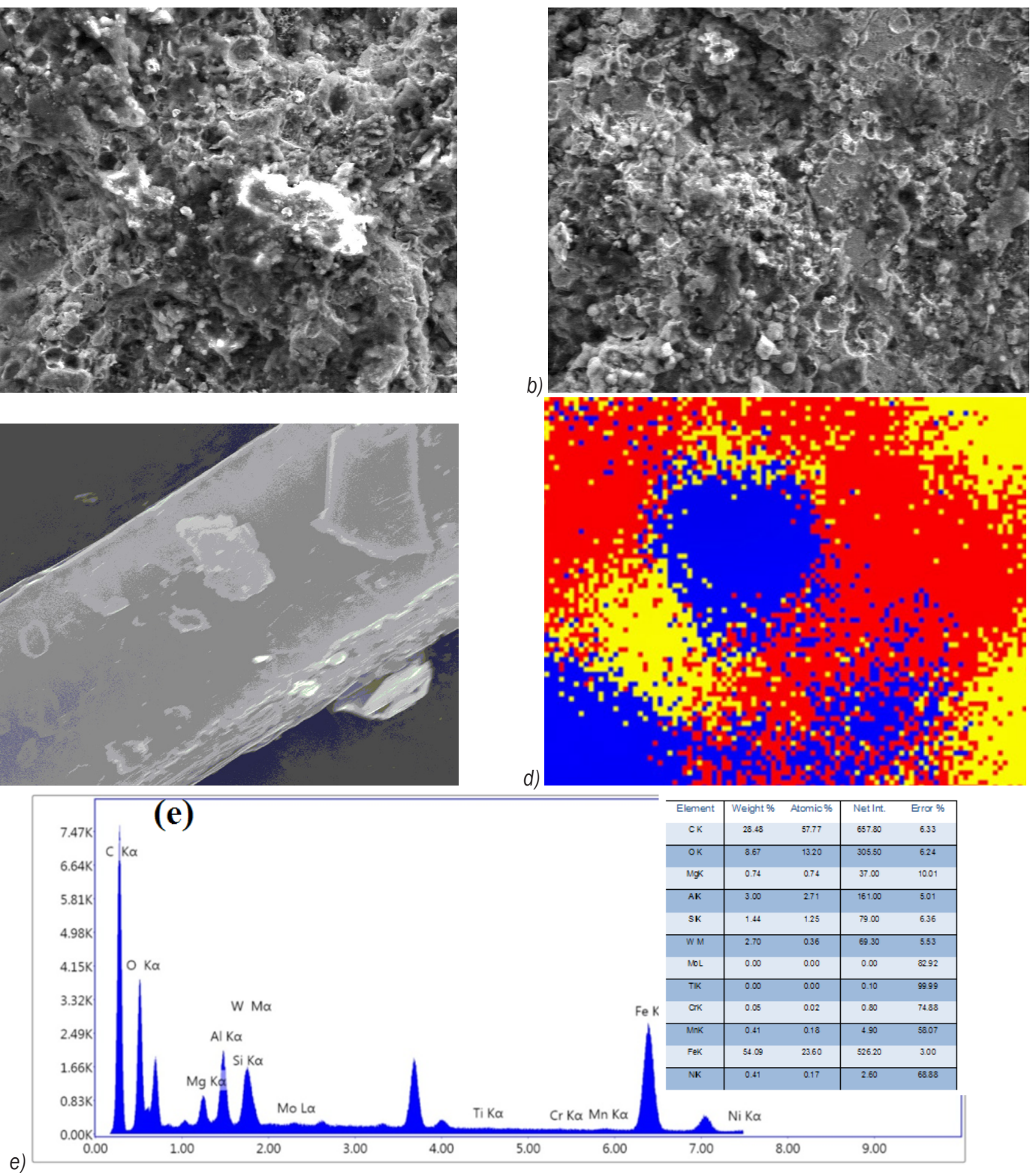

e)

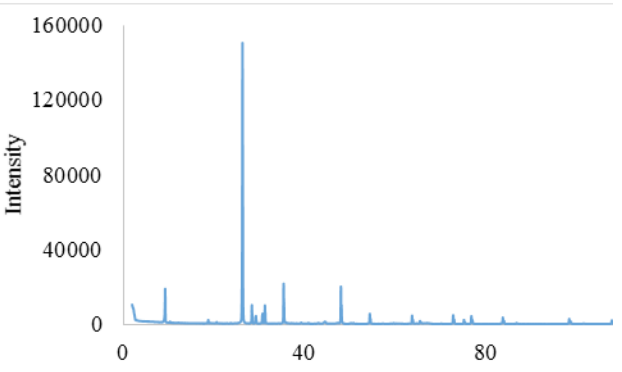

g)

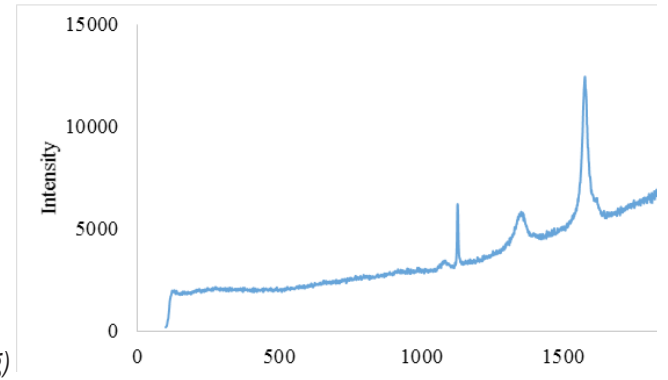

Fig. 1. Coating characterization; a) to c) SEM; d) to e) EDS mapping result; f) HRXRD; g) Raman spectra image of coating

test condition of temperature ranging from $50{ }^{\circ} \mathrm{C}$ to $350{ }^{\circ} \mathrm{C}$, load from $60 \mathrm{~N}$ to $90 \mathrm{~N}$ and sliding velocity from $0.1 \mathrm{~m} / \mathrm{s}$ to $0.4 \mathrm{~m} / \mathrm{s}$ respectively increases residual stress rapidly decreases from $-50 \mathrm{HV}$ to $-11 \mathrm{HV}$. The residual stress was found to decrease to $78 \%$ at test condition of $90 \mathrm{~N}$ load, $0.4 \mathrm{~m} / \mathrm{s}$ sliding velocity and $350{ }^{\circ} \mathrm{C}$ temperature. Compressive residual stresses are established due to the bombardment of high- 
a)

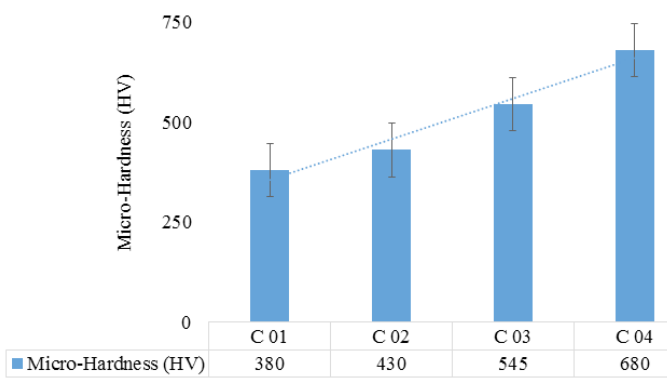

b)

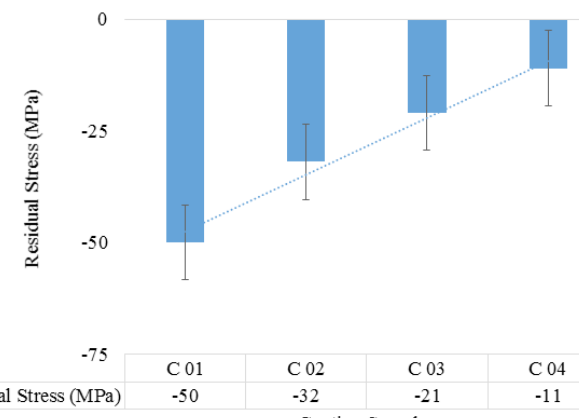

Coating Samples

Fig. 2. a) Micro-hardness vs. coating graph; and b) residual stress of coating vs. coating graph
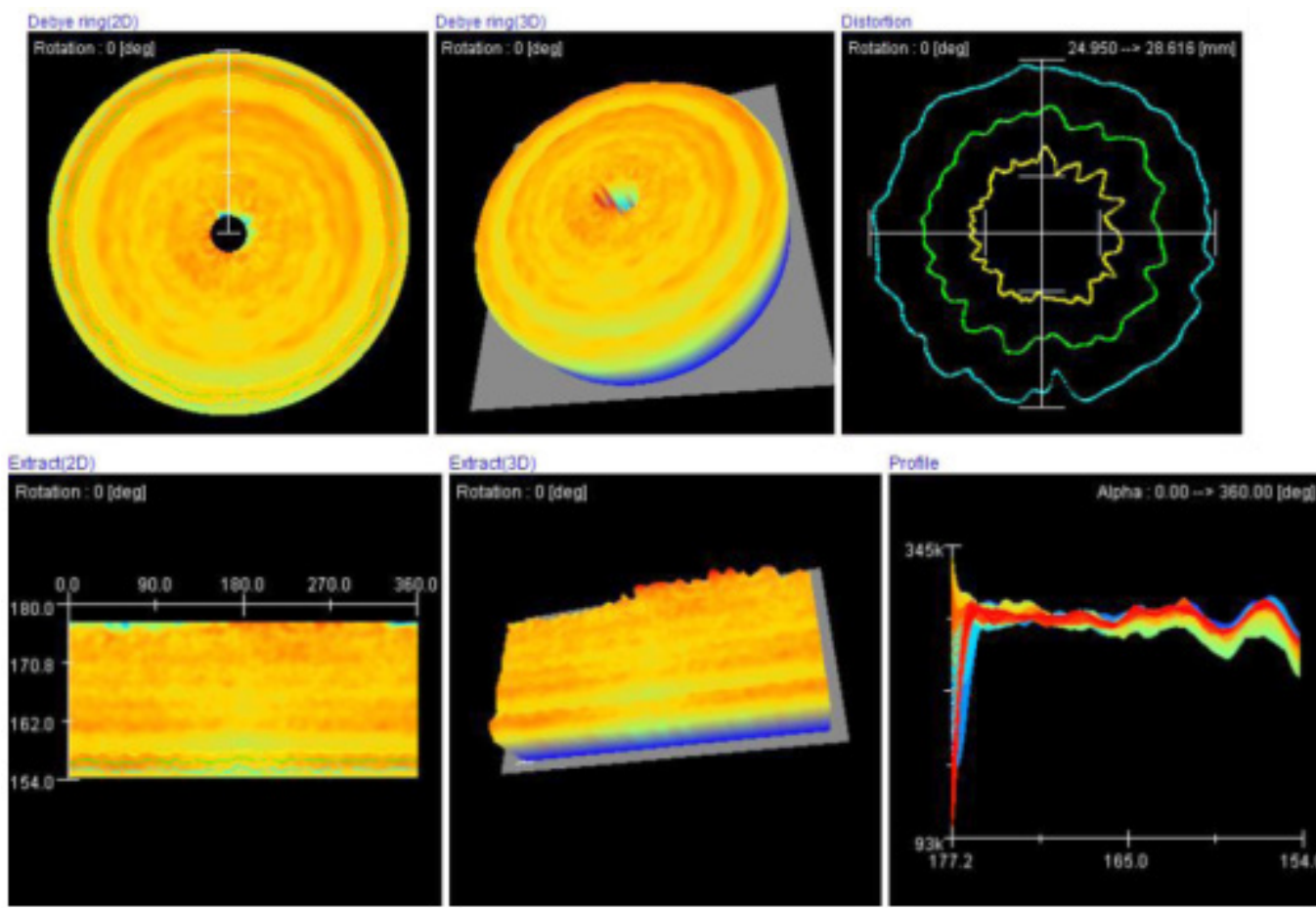

Fig. 3. Residual stress of coating; a) Debye ring (2D), b) Debye ring (3D), c) distortion, d) extract (2D), e) extract (3D), and f) profile

velocity particles on the substrate material. Further increases in temperature, load and sliding velocity during the tribological test, and tensile stresses as internal stresses are developed, which balances the compressive stresses developed due to bombardment of hard ceramics particles [29] and [33]. Skordaris et al. [34] reported that as the temperature increases, thermal stresses on the coating also increases, but the structural stress developed on the samples remains stable up to $400{ }^{\circ} \mathrm{C}$.

$$
\begin{gathered}
\sigma_{x}=\frac{E}{1+v} \cdot \frac{1}{\sin 2 \eta} \cdot \frac{1}{\sin 2 \Psi_{0}} \cdot \frac{\partial \varepsilon \alpha_{1}}{\partial \cos \alpha}, \\
\sigma_{y}=\frac{E}{2(1+v)} \cdot \frac{1}{\sin 2 \eta} \cdot \frac{1}{\sin 2 \Psi_{0}} \cdot \frac{\partial \varepsilon \alpha_{2}}{\partial \cos \alpha},
\end{gathered}
$$

where $\sigma_{x}$ and $\sigma_{y}$ is residual stress developed on the surface at the $x$ - and $y$-axis, respectively, $v$ is Poisson ratio, $\eta$ is diffraction lattice angle, $\psi_{0}$ is $\mathrm{X}$-rays incident angle and $\alpha$ is the azimuth angle of Debye ring, $E$ is Young's modulus.

\subsection{Corrosion test}

Fig. 4 shows the experimental test results of mass loss during corrosion test. The experimental results of corrosion test for the hybrid composite coating shows that as the test condition increases mass loss due to corrosion rapidly decreases from $0.10 \mathrm{~g}$ to $0.04 \mathrm{~g}$, when samples were dipped for $1 \mathrm{~h}$. When samples were dipped for $8 \mathrm{~h}$, the mass loss of hybrid composite 
coating varies from $0.12 \mathrm{~g}$ to $0.045 \mathrm{~g}$. The mass loss was found to decrease by $60 \%$ at $1 \mathrm{~h}$ and $62.5 \%$ at $8 \mathrm{~h}$. During the corrosion test, the samples after high temperature wear test were dipped in the electrolytic solution for $1 \mathrm{~h}$ and $8 \mathrm{~h}$. The trend of mass loss shows linear relation with time due to corrosion with no acceleration, incubation or steady stage. The presence of carbon and hydrogen leads to a graphitization effect and the formation of sulphide forms a thin solid lubricated layer [30] and [33].

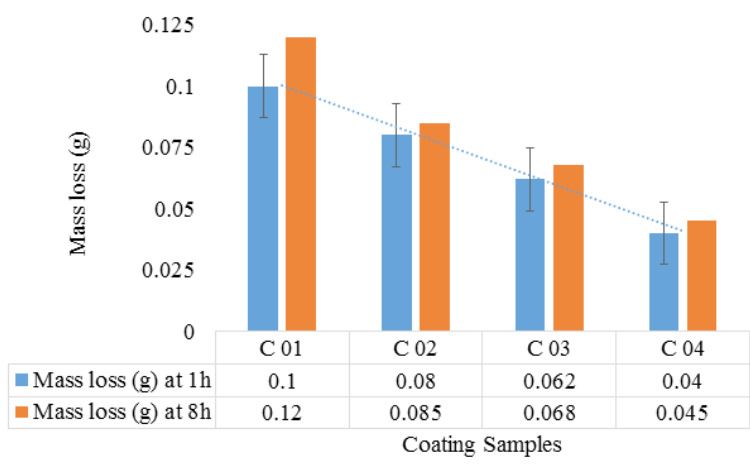

Fig. 4. Corrosion test of coating

\subsection{Tribological Test}

The tribological performance was evaluated using pinon-disk tribometer, which showed COF in the range of 0.12 to 0.52 , as shown in Fig. 5a, while Fig. 5b shows that wear was in the range of $45 \mu \mathrm{m}$ to $120 \mu \mathrm{m}$, at test condition of temperature ranging from $50{ }^{\circ} \mathrm{C}$ to $350{ }^{\circ} \mathrm{C}$, load from $60 \mathrm{~N}$ to $90 \mathrm{~N}$ and sliding velocity from $0.1 \mathrm{~m} / \mathrm{s}$ to $0.4 \mathrm{~m} / \mathrm{s}$, respectively. The tribological analysis of carbon-based hybrid composite coating was done to evaluate the wear behaviour for wear resistance applications. The tribological test showed a $76.9 \%$ decrease in COF and a $62.5 \%$ reduction in the wear at test condition of $0.4 \mathrm{~m} / \mathrm{s}$ sliding velocity, 350 ${ }^{\circ} \mathrm{C}$ temperature, and $90 \mathrm{~N}$ load. During wear testing $\mathrm{COF}$, the wear values first increase and, after that, become stable during the running-in process between the composite coating and its counterpart, due to good interfacial strength and excellent adhesive strength. The presence of carbon and hydrogen leads to a graphitization effect, and the formation of sulphide forms a thin solid lubricated layer [30] and [33]. Tyagi et al. [30] and Matikainen et al. [31] investigated an HVOF-developed coating, and the experimental result shows that higher velocity particles enhance the wear resistance properties of the developed coating; similar trends were also attained in the present tribological study. The experimental results that as the load, velocity, and temperature increases, $\mathrm{COF} \&$ wear behaviour of carbon coating decreases significantly according to the Stribeck theory [35], and similar trends were also found in the present tribological study. The deviation of friction and wear by sliding distance shows approximately $500 \mathrm{~m}$ run-in-stage, followed by a stable stage [36].

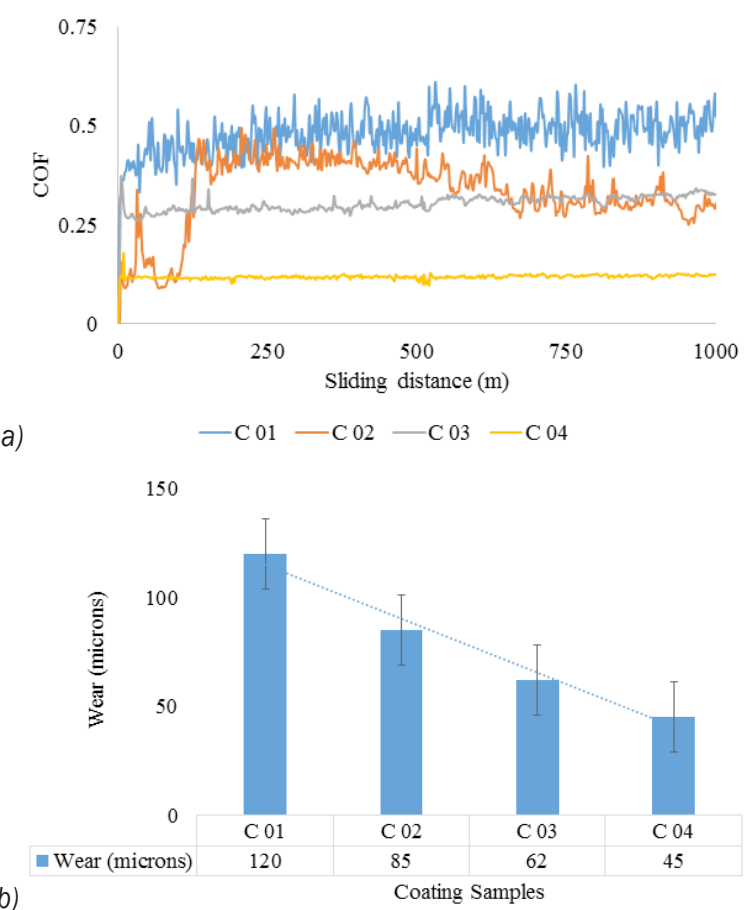

Fig. 5. a) COF; and b) wear of carbon coating

\subsection{Wear Mechanism}

The FESEM images show the wear characteristics of worn surfaces of the developed carbon-based hybrid composite coatings, and shown in Fig. 6a and b. Fig. $6 \mathrm{c}$ shows the cross-sectional image of the composite coating after the wear test. FESEM obtained after wear test shows a brittle structure with grains along with the conversion of amorphous to polycrystalline structure of the composite coating. It was quite clear that metallic abrasive particles are entrenched in the developed composite coating or adhesive wear. The carbon-based hybrid composite coating shows ploughing action with the presence of chipped-off particles, rubbing action along with worn out particles were seen during the wear test [33]. It is also noted that the formation of tribofilm and diffusion of carbon particles increases as the test conditions increases [30] and [36]. 


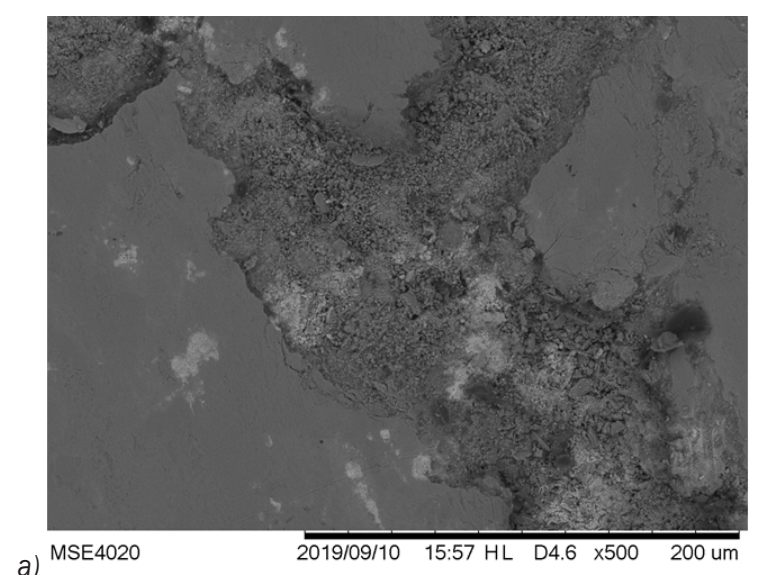

a)
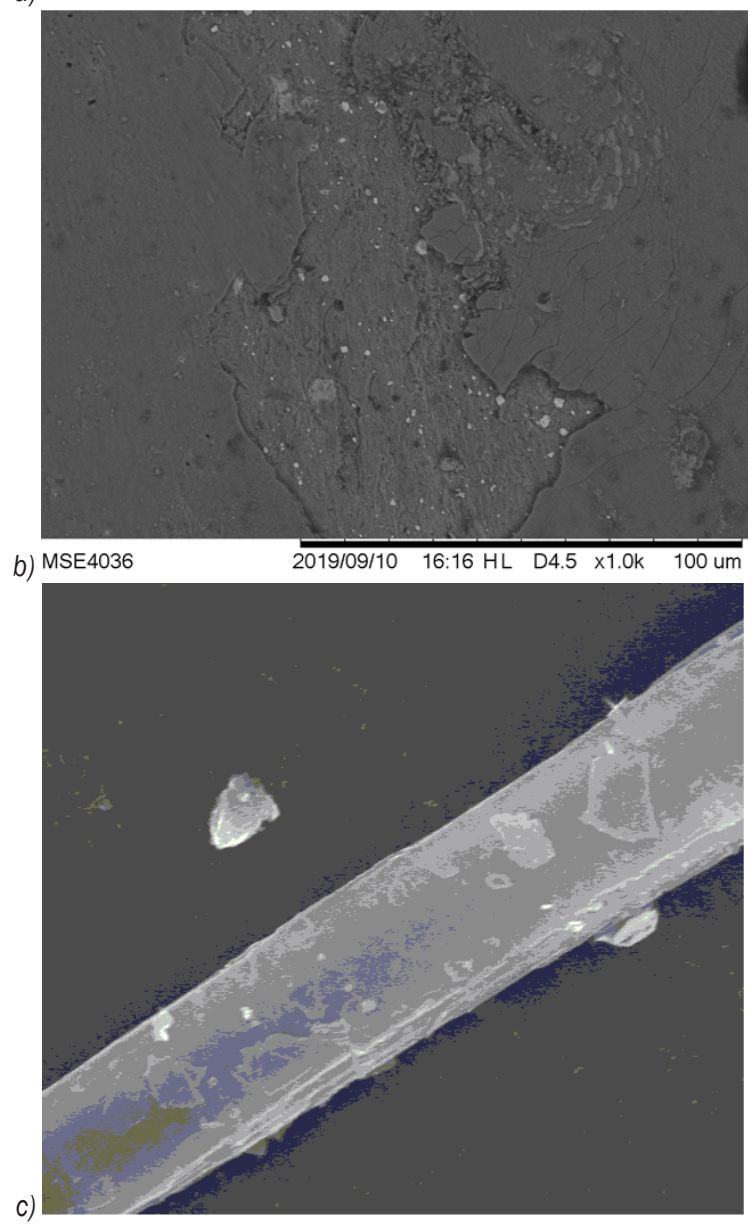

Fig. 6. a) and b) wear mechanism, and c) coating thickness of carbon coating

\section{CONCLUSIONS}

Currently, cost-effective coatings that cause less pollution are in strong demand; to reduce frictional loss, carbon-based hybrid composite coatings have been deposited using an HVOF process. The present work evaluates the microstructure, surface morphology, tribological and mechanical properties of carbon-based hybrid composite coating for wear resistance applications.

The major results of carbon coatings are:

1. FESEM+EDS, HRXED \& Raman spectra confirm the deposition of coating, which exhibits typical semi-molten, molten and un-melted grains of composite particles along with the formation of lamellae.

2. The carbon-based hybrid composite coatings exhibit a typical laminar and molten structure, which showed micro-hardness in the range of 380 $\mathrm{HV}$ to $680 \mathrm{HV}$ and residual stress from $-11 \mathrm{MPa}$ to $-50 \mathrm{MPa}$.

3. The corrosion test result shows that as the test conditions increases, the mass loss decreases from $0.10 \mathrm{~g}$ to $0.04 \mathrm{~g}$, when samples were dipped for $1 \mathrm{~h}$; when the samples were dipped for $8 \mathrm{~h}$, the mass loss of hybrid composite coating varies from $0.12 \mathrm{~g}$ to $0.045 \mathrm{~g}$.

4. The tribological performance was evaluated using a high-temperature tribometer, which showed COF in the range of 0.12 to 0.52 , while wear in the range of $45 \mu \mathrm{m}$ to $120 \mu \mathrm{m}$, as the test condition of temperature ranging from $50{ }^{\circ} \mathrm{C}$ to $350{ }^{\circ} \mathrm{C}$, load from $60 \mathrm{~N}$ to $90 \mathrm{~N}$ and sliding velocity from $0.1 \mathrm{~m} / \mathrm{s}$ to $0.4 \mathrm{~m} / \mathrm{s}$, respectively.

5. The tribological test showed a $78.9 \%$ increase in micro-hardness, a $78 \%$ decrease in residual stress, $60 \%$ and $62.5 \%$ decreases in mass loss due to corrosion at $1 \mathrm{~h}$ and $8 \mathrm{~h}$, respectively, a $76.9 \%$ decrease in COF and a $62.5 \%$ reduction in the wear at test condition of $350{ }^{\circ} \mathrm{C}$ temperature, a sliding velocity of $0.4 \mathrm{~m} / \mathrm{s}$ and $90 \mathrm{~N}$ load.

\section{REFERENCES}

[1] Basumatary, J., Nie, M., Wood, R.J.K. (2015). The synergistic effects of cavitation erosion- corrosion in ship propeller materials. Journal of Bio- and Tribo-Corrosion, vol. 1, no. 12, DOI:10.1007/s40735-015-0012-1.

[2] Jasionowski, R., Przetakiewicz, D., Przetakiewicz, W. (2014). Cavitation erosion resistance of alloys used in cathodic protection of hulls of ships. Archives of Metallurgy and Materials, vol. 59, D0l:10.2478/amm-2014-0039.

[3] Plesset, M.S., Prosperetti, A. (1977). Bubble dynamics and cavitation. Annual Review of Fluid Mechanics, vol. 9, p. 145185, Dol:10.1146/annurev.fl.09.010177.001045.

[4] Philipp, A., Lauterborn, W. (1998). Cavitation erosion by single laser-produced bubbles. Journal of Fluid Mechanics, vol. 361, p. 75-116, D0I:10.1017/S0022112098008738.

[5] Lin, J., Wang, Z., Cheng, J., Kang, M., Fu, X., Hong, S. (2017). Effect of initial surface roughness on cavitation erosion resistance of arc-sprayed Fe-based amorphous/ 
nanocrystalline coatings. Coatings, vol. 7, no. 11, art. ID 200, DOI:10.3390/coatings7110200.

[6] Shi, Z., Wang, J., Wang, Z., Qiao, Y., Xiong, T., Zheng, Y. (2018). Cavitation erosion and jet impingement erosion behavior of the NiTi coating produced by air plasma spraying. Coatings, vol. 8, no. 10, art ID 346, D0I:10.3390/coatings8100346.

[7] Qiao, L., Wu, Y., Hong, S., Cheng, J. (2019). Ultrasonic cavitation erosion mechanism and mathematical model of HVOF sprayed Fe-based amorphous/nanocrystalline coatings. Ultrasonics Sonochemistry, vol. 52, p. 142-149, D0I:10.1016/j.ultsonch.2018.11.010.

[8] Wood, R.J.K., Herd, S., Thakare, M.R. (2018). A critical review of the tribocorrosion of cemented and thermal sprayed tungsten carbide. Tribology International, vol. 119, p. 491509, D0I:10.1016/j.triboint.2017.10.006.

[9] Singh, J., Thakur, L., Angra, S. (2020). Abrasive wear behavior of WC-10Co-4Cr cladding deposited by TIG welding process. International Journal of Refractory Metals and Hard Materials, vol. 88, art. ID 105198, D0l:10.1016/j.ijrmhm.2020.105198.

[10] Singh, J., Thakur, L., Angra, S. (2020). An investigation on the parameter optimization and abrasive wear behaviour of nanostructured WC-10Co-4Cr TIG weld cladding. Surface and Coating Technology, vol. 386, art. ID 125474, D0I:10.1016/j. surfcoat.2020.125474.

[11] Gant, A.J., Gee, M.G. (2015). Wear modes in slurry jet erosion of tungsten carbide hard metals: their relationship with microstructure and mechanical properties. International Journal of Refractory Metals and Hard Materials, vol. 49, p. 192-202, D0l:10.1016/j.jirmhm.2014.07.036.

[12] Gant, A.J., Morrell, R., Wronski, A.S., Jones, H.G. (2018). Edge toughness of tungsten carbide based hard metals. International Journal of Refractory Metals and Hard Materials, vol. 75, p. 262-278, Dol:10.1016/j.ijrmhm.2017.12.020.

[13] Zhang, H., Gong, Y., Chen, X., McDonald, A., Li, H. (2019). A comparative study of cavitation erosion resistance of several HVOF-sprayed coatings in deionized water and artificial seawater. Journal of Thermal Spray Technology, vol. 28, p. 1060-1071, D0I:10.1007/s11666-019-00869-x.

[14] Williamson, E.H., Gee, M., Robertson, D., Watts, J.F., Whiting, M.J., Yeomans, J.A. (2019). Wear performance and characterisation of coatings for nuclear applications: WC(W,Cr)2C-Ni and hard chromium plate. Wear, vol. 430-431, p. 169-182, Dol:10.1016/j.wear.2019.05.001.

[15] da Silva, F.S., Cinca, N., Dosta, S., Cano, I.G., Couto, M., Guilemany, J.M., Benedetti, A.V. (2018). Corrosion behavior of WC-Co coatings deposited by cold gas spray onto AA 7075T6. Corrosion Science, vol. 136, p. 231-243, D0l:10.1016/j. corsci.2018.03.010.

[16] Rovatti, L., Lecis, N., Dellasega, D., Russo, V., Gariboldi, E. (2018). Influence of aging in the temperature range 250$350{ }^{\circ} \mathrm{C}$ on the tribological performance of a WC-CoCr coating produced by HVOF. International Journal of Refractory Metals and Hard Materials, vol. 75, p. 218-224, D0l:10.1016/j. ijrmhm.2018.04.017.

[17] Cheng, J.B., Liang, X.B., Xu, B.S. (2013). Devitrification of arc-sprayed FeBSiNb amorphous coatings: Effects on wear resistance and mechanical behavior. Surface and
Coatings Technology, vol. 235, p. 720-726, D0l:10.1016/j. surfcoat.2013.08.054.

[18] Hong, S., Lin, J., Wu, Y., Wu, J., Zheng, Y., Zhang, Y., Sun, W. (2020). Cavitation erosion characteristics at various flow velocities in $\mathrm{NaCl}$ medium of carbide-based cermet coatings prepared by HVOF spraying. Ceramics International, vol. 47, no. 2, p. 1929-1939, D0l:10.1016/j.ceramint.2020.09.022.

[19] Ludwig, G.A., Malfatti, C.F., Schroeder, R.M., Ferrari, V.Z., Muller, I.L. (2019). WC10Co4Cr coatings deposited by HVOF on martensitic stainless steel for use in hydraulic turbines: resistance to corrosion and slurry erosion. Surface and Coatings Technology, vol. 377 art. ID 124918, D0I:10.1016/j. surfcoat.2019.124918.

[20] Ma, N., Guo, L., Cheng, Z., Wu, H., Ye, F., Zhang, K. (2014). Improvement on mechanical properties and wear resistance of HVOF sprayed WC-12Co coatings by optimizing feedstock structure. Applied Surface Science, vol. 320, p. 364-371, DOl:10.1016/j.apsusc.2014.09.081.

[21] Ding, X., Ke, D., Yuan, C.Q., Ding, Z.X., Cheng, X.D. (2018). Microstructure and cavitation erosion resistance of HVOF deposited WC-Co coatings with different sized WC. Coatings, vol. 8, no. 9, art. ID 307, D0l:10.3390/coatings8090307.

[22] Cho, T.Y., Yoon, J.H., Kim, K.S., Song, K.O., Joo, Y.K., Fang, W., Zhang, S.H., Youn, S.J., Chun, H.G., Hwang, S.Y. (2008). A study on HVOF coatings of micron and nano WC-Co powders. Surface and Coatings Technology, vol. 202, no. 22-23, p. 5556-5559, D0l:10.1016/j.surfcoat.2008.06.106.

[23] Wang, X., Ouyang, T., Duan, X., Ke, C., Zhang, X., Min, J., Li, A., Guo, W., Cheng, X. (2017). Improved solar absorptance of WC/Co solar selective absorbing coating with multimodal WC particles. Metals, vol. 7, no. 4, art ID 137, D0l:10.3390/ met7040137.

[24] Al-Mutairi, S., Hashmi, M., Yilbas, B., Stokes, J. (2015). Microstructural characterization of HVOF/plasma thermal spray of micro/nano WC-12\%Co powders. Surface and Coatings Technology, vol. 264, p. 175-186, D0l:10.1016/j. surfcoat.2014.12.050.

[25] Wentzel, E.J., Allen, C. (1997). The erosion-corrosion resistance of tungsten-carbide hard metals. International Journal of Refractory Metals and Hard Materials, vol. 15, no. 1-3, p. 81-87, Dol:10.1016/S0263-4368(96)00016-9.

[26] Tyagi, A., Walia, R.S., Murtaza, Q. (2019). Tribological behavior of temperature dependent environment friendly thermal CVD diamond coating. Diamond \& Related Materials, vol. 96, p. 148-159, D0I:10.1016/j.diamond.2019.05.003.

[27] Manninen, N.K., Ribeiro, F., Escudeiro, A., Polcar, T., Carvalho, S., Cavaleiro, A. (2013). Influence of Ag content on mechanical and tribological behavior of DLC coatings. Surface and Coatings Technology, vol. 232, p. 440-446, D0l:10.1016/j. surfcoat.2013.05.048.

[28] Casiraghi, C., Ferrari, A.C., Robertson, J. (2005). Raman spectroscopy of hydrogenated amorphous carbons. Physical Review B, vol. 72, no. 8, art. ID 085401, D0l:10.1103/ PhysRevB.72.085401.

[29] Tyagi, A., Pandey, S.M., Gupta, K., Walia, R.S., Murtaza, O., Krishen, K. (2019). Tribological behavior of sustainable Carbon based Composite coating for wear resistance 
applications. Materials Research Express, vol. 6, no. 12, DOI:10.1088/2053-1591/ab52b4.

[30] Tyagi, A., Pandey, S.M., Walia, R.S., Murtaza, Q. (2019). Characterization and parametric optimization of tribological properties of Mo blend composite coating. Material Research Express, vol. 6, no. 8, D0l:10.1088/2053-1591/ab1d0a.

[31] Matikainen, V., Koivuluoto, H., Vuoristo, P., Schubert, J., Houdková, Š. (2018). Effect of nozzle geometry on the microstructure and properties of HVAF-sprayed WC-10C04Cr and $\mathrm{Cr} 3 \mathrm{C} 2-25 \mathrm{NiCr}$ coatings. Journal of Thermal Spray Technology, vol. 27, p. 680-694, D0l:10.1007/s11666-0180717-z.

[32] Wu, H., Lan, X.D., Liu, Y., Li, F., Zhang, W.D., Chen, Z.J., Zai, X.F., Zeng, H. (2016). Fabrication, tribological and corrosion behaviors of detonation gun sprayed Fe-based metallic glass coating. Transactions of Nonferrous Metals Society of China, vol. 26, no. 6, p. 1629-1637, D0l:10.1016/S10036326(16)64271-1.

[33] Tyagi, A., Walia, R.S., Murtaza, Q. (2019). Tribological behavior of HVOF carbon coating for wear resistance applications.
Materials Research Express, vol. 6, no. 12, D0I:10.1088/20531591/ab555d.

[34] Skordaris, G., Bouzakis, K.-D., Charalampous, P., Kotsanis, T., Bouzakis, E., Lemmer, O. (2016). Effect of structure and residual stresses of diamond coated cemented carbide tools on the film adhesion and developed wear mechanisms in milling. CIRP Annals, vol. 65, no. 1, p. 101-104, D0l:10.1016/j. cirp.2016.04.007.

[35] Biberger, J., Füßer, H.-J. (2017). Development of a test method for a realistic, single parameter-dependent analysis of piston ring versus cylinder liner contacts with a rotational tribometer. Tribology International, vol. 113, p. 111-124, D0l:10.1016/j. triboint.2016.10.043.

[36] Tyagi, A., Pandey, S.M., Murtaza, Q., Walia, R.S., Tyagi, M. (2020). Tribological behavior of carbon coating for piston ring applications using Taguchi approach. Materials Today: Proceeding, vol. 25, p. 759-764, D0l:10.1016/j. matpr.2019.09.004. 